\title{
Raman classification of the glass beads excavated on Mapungubwe hill and K2, two archaeological sites in South Africa.
}

\author{
Aurélie Tournié $^{\mathrm{a}, \mathrm{b}}$, Linda C Prinsloo ${ }^{\mathrm{a}^{*}}$, Philippe Colomban ${ }^{\mathrm{b}}$ \\ ${ }^{a}$ Department of Physics University of Pretoria, Pretoria 0002, South Africa. \\ ${ }^{b}$ Laboratoire Dynamique, Interactions et Réactivité (LADIR), UMR 7075, CNRS - Université Pierre et \\ Marie Curie, 2 rue Henri Dunant, 94320 Thiais, France.
}

\begin{abstract}
About two hundred coloured glass beads (red, yellow, green, blue, white, black, pink, plum) excavated on Mapungubwe hill and at K2, archaeological sites in the Limpopo valley South Africa, have been studied with Raman scattering. This is also the most southern site in Africa where evidence for glass reworking has been found. The glass matrix of the beads was classified according to its Raman signature into 3 main subgroups and corroded glass could also be identified. At least seven different chromophores or pigments (lazurite, lead tin yellow type II, $\mathrm{Ca} / \mathrm{Pb}$ arsenate, chromate, calcium antimonate, Fe-S "amber" and a spinel) have been identified. Many of the pigments were manufactured after the $13^{\text {th }}$ century, confirming the presence of modern beads in the archaeological record. This calls for further research to find a way to reconcile the carbon dating of the hill, which currently gives the last occupation date on the hill as $1290 \mathrm{AD}$ with the physical evidence of the modern beads excavated on the hill. The results are and discussed in terms of the glass production origin of the beads (Europe, Mediterranean area, India, China,..).
\end{abstract}

\section{Key-words}

Raman Spectroscopy, beads, trade, Africa, Mapungubwe

$\begin{array}{ll}\text { Corresponding author: } & \text { Linda C Prinsloo } \\ & \text { Department of Physics } \\ & \text { University of Pretoria } \\ & \text { Pretoria } \\ & \text { South Africa } \\ & 27124202458 \\ & \text { linda.prinsloo@up.ac.za }\end{array}$




\section{INTRODUCTION}

Mapungubwe is a small flat-topped sandstone plateau situated in the Limpopo valley close to the present-day borders of South Africa, Botswana and Zimbabwe (Fig. 1). Excavations on Mapungubwe hill during 1933-1934 exposed three "royal" burials in which gold funerary objects, beads and bangles, were found together with imported glass beads. ${ }^{1}$ The sheer volume of beads recovered is remarkable; from one burial alone 26037 glass beads were counted. ${ }^{2,3}$ Shortly after the discovery of Mapungubwe another archaeological site, namely Bambandyanalo (later renamed $\mathrm{K} 2$ ), approximately $1 \mathrm{Km}$ to the southwest of Mapungubwe hill, was also discovered. During subsequent excavations at both sites (1934-1940) thousands more glass beads were found. ${ }^{4}$

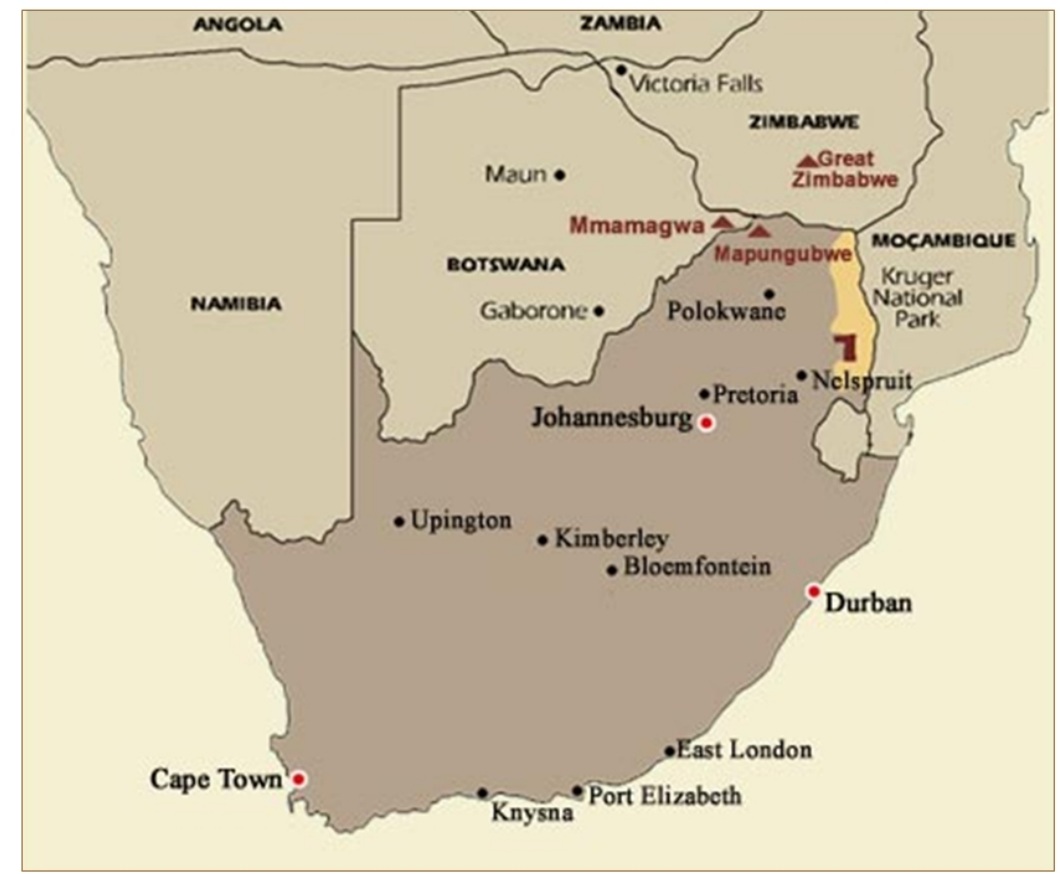

Figure 1: Location of Mapungubwe sites at the confluence of the Limpopo and Shashe rivers close to the present-day borders of South Africa, Botswana and Zimbabwe.

Exotic imports, when found in an archaeological context, are clear proof of international trade and if the provenance of the object can be determined, light can be shed on trade routes and even roughly date the site. Glass beads are the most abundant of the imported trade goods that have been excavated at archaeological sites all over Africa and the central position of Mapungubwe hill, at the confluence of the Limpopo and Shashe rivers, made it from the earliest time accessible to Central Africa, Egypt, the Mediterranean world and trade around the Indian ocean, which stretched as far as 
China. ${ }^{2}$ Possible trading partners were therefore numerous and the potential origin of the beads widespread.

Not all the beads were imported. "Garden Roller" beads (Fig. 2, Fig. 3 indicated as GR) shaped like the heavy rollers used to level grass lawns were discovered at Bambandyanalo (K2) in 1934. The discovery of broken (and one whole) clay moulds at $\mathrm{K} 2$, into which the beads fit perfectly, proved that the beads were manufactured on site. ${ }^{4}$ It is the most southern site in Africa where evidence of glassreworking has been discovered and it was shown that the beads were manufactured by heating smaller glass trade beads found in association with the large "Garden Rollers" up to the temperature required for sintering and glass formation. ${ }^{2,6}$

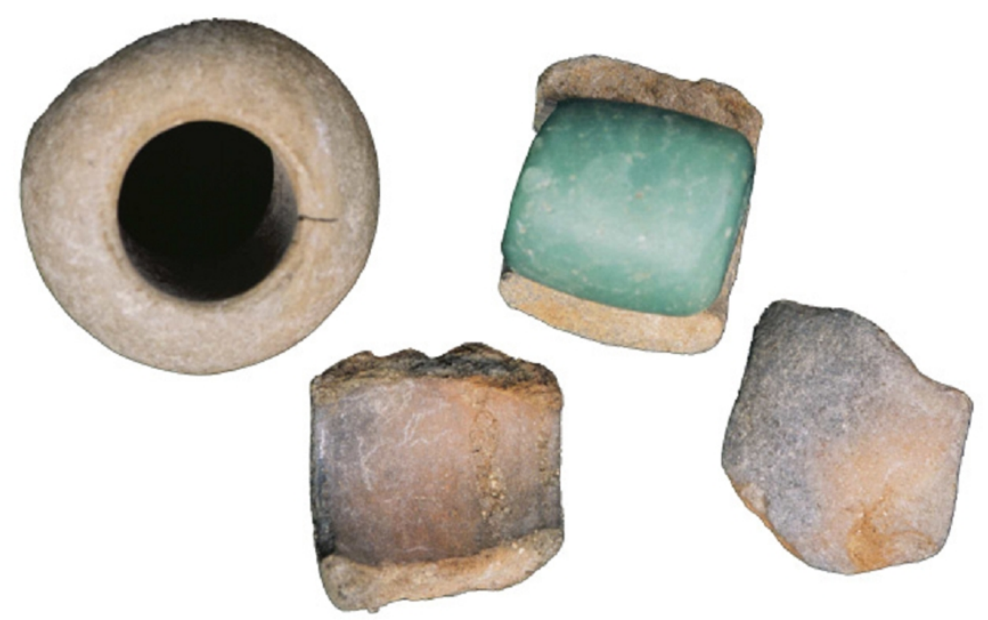

Figure 2: Garden Roller clay moulds and bead (bead diameter 12-15 mm; photograph from Mapungubwe Museum Collection).

Initial studies on the beads found during the early excavations classified them according to morphological appearances, specific gravity tests and fluorescence measurements. ${ }^{7-9}$ India, Fustat (Egypt) and Venice were proposed as origin for the beads. Various studies, in which X-ray fluorescence (XRF), neutron activation analysis (NAA), X-ray powder diffraction (XRD) and rare earth elemental analyses (REE) were used, have been undertaken to chemically analyse the beads, but the exact origin of most of the beads is still unknown. ${ }^{2,3,5,6,10,11,13}$

Recently Wood proposed a classification system for the beads excavated at various archaeological sites in southern Africa, including Mapungubwe and K2, according to their morphological and technological attributes and dated each series by reference to established radiocarbon chronologies. ${ }^{6,14}$ We follow her classification system and Table 1 summarizes the beads' series, namely Zhizo (after the site where 
they were first discovered), K2 (after the K2 site), Garden Rollers, Indo-Pacific (an established group named by Francis ${ }^{15}$ ) and Mapungubwe Oblates (named by Davison $^{10,11}$ ). A few large Islamic beads were also found at Mapungubwe, but not analysed in this study. She also described a Zimbabwe and Khami bead series, of which she did not find examples amongst the beads she studied from the Mapungubwe and K2 sites. Not many of the oldest type of beads, namely the Zhizo beads, occur at Mapungubwe and K2 and they are usually heavily corroded. K2 type beads are the predominant kind of bead discovered at the $\mathrm{K} 2$ site, but many were also excavated in the earlier layers on Mapungubwe hill. Garden Rollers and their moulds occur mostly at K2, but a few beads were also excavated on Mapungubwe hill, where no moulds were discovered. Indo-Pacific beads occur at both sites and the Mapungubwe oblates are associated with the graves and occupational layers on Mapungubwe, but at K2 only appear in graves and are therefore seen as intrusive from the hill.

\begin{tabular}{|c|c|c|c|c|c|}
\hline Bead series & $\begin{array}{l}\text { Period } \\
\text { traded in } \\
\text { southern } \\
\text { Africa } \\
\end{array}$ & $\begin{array}{l}\text { Method of } \\
\text { manufacture }\end{array}$ & Size & Colour & Shape \\
\hline Zhizo & $\begin{array}{l}\text { ca. AD 8- } \\
1000\end{array}$ & Drawn & $\begin{array}{l}2.5-13 \mathrm{~mm} \\
\text { diameter } \\
\text { up to } 20 \\
\text { mm long } \\
\end{array}$ & $\begin{array}{l}\text { Cobalt, yellow, blue- } \\
\text { green, green }\end{array}$ & Tubes \\
\hline K2 & $\begin{array}{l}\text { ca. AD 980- } \\
1200\end{array}$ & Drawn & $\begin{array}{c}\text { Small } \\
2-3.5 \mathrm{~mm} \\
\text { diameter } \\
1.2-4 \mathrm{~mm} \\
\text { long }\end{array}$ & $\begin{array}{l}\text { Transparent to } \\
\text { translucent blue- } \\
\text { green to light green }\end{array}$ & $\begin{array}{l}\text { Tubes, } \\
\text { cylinders }\end{array}$ \\
\hline $\begin{array}{l}\text { Garden } \\
\text { Roller }\end{array}$ & $\begin{array}{l}\text { ca. AD 980- } \\
1200\end{array}$ & $\begin{array}{l}\text { Re-melted K2 } \\
\text { series beads in } \\
\text { single-use clay } \\
\text { mould }\end{array}$ & $\begin{array}{c}\text { Large } \\
10 \text { to14 } \mathrm{mm} \\
\text { diameter to } \\
7 \text { to } 15 \mathrm{~mm} \\
\text { long } \\
\end{array}$ & $\begin{array}{l}\text { Transparent to } \\
\text { translucent blue- } \\
\text { green to light green }\end{array}$ & Barrel-shaped \\
\hline Indo-Pacific & $\begin{array}{l}\text { ca. AD } \\
1000-1250\end{array}$ & $\begin{array}{l}\text { Drawn } \\
\text { Heat rounded }\end{array}$ & $\begin{array}{l}\text { Vary but } \\
\text { most are } 2.5 \\
\text { to } 4.5 \mathrm{~mm} \\
\text { diameter }\end{array}$ & $\begin{array}{l}\text { Black and brownish- } \\
\text { red beads are opaque; } \\
\text { yellow, soft orange, } \\
\text { green and blue-green } \\
\text { are translucent }\end{array}$ & $\begin{array}{l}\text { Vary but most } \\
\text { are cylindrical }\end{array}$ \\
\hline $\begin{array}{l}\text { Mapungubwe } \\
\text { oblate }\end{array}$ & $\begin{array}{l}\text { ca. AD } \\
1240-1300\end{array}$ & $\begin{array}{l}\text { Drawn, } \\
\text { Heat rounded }\end{array}$ & $\begin{array}{l}\text { Uniform } \\
2 \text { to } 3.5 \mathrm{~mm} \\
\text { diameter }\end{array}$ & $\begin{array}{l}\text { Black, cobalt blue, } \\
\text { green, yellow, plum, } \\
\text { turquoise, bright } \\
\text { orange }\end{array}$ & $\begin{array}{c}\text { Uniform } \\
\text { Oblate or } \\
\text { cylindrical } \\
\text { with well- } \\
\text { rounded end }\end{array}$ \\
\hline
\end{tabular}


The current view, based on carbon dating, is that the $\mathrm{K} 2$ site dates between 1030-1220AD and that the occupation on Mapungubwe hill lasted to 1290 AD when the site was permanently abandoned. ${ }^{12}$ Therefore the beads that Wood used for classification purposes from these two sites are only from this period, where she could link the beads to carbon dates. However, in his report on the 1937-1940 excavations at the sites, Gardner described a class of bead that he regarded as more modern as it was found in the top layers of the excavation and according to him some of the beads originated from Europe (large blue hexagonals, red beads with green centre and pink beads). ${ }^{4}$ This was one of the reasons why the early excavators such as Gardner, estimated the last occupation date on the hill to be the middle of the $19^{\text {th }}$ century. ${ }^{4}$ The existence of these beads has been ignored in studies on the beads after the seventies, although they are part of the formal Mapungubwe bead collection.

The colouring elements used in beads imported into southern Africa before the $14^{\text {th }}$ century were determined by elemental analysis as iron, lead, tin, copper and cobalt. ${ }^{13}$ The association of $\mathrm{Pb}$ with $\mathrm{Sn}$ in yellow glass indicated that lead stannate (lead tin yellow type 1 or 2) was the preferred yellow pigment, particularly for plant ash glasses. ${ }^{13,16,17}$ Iron dissolved as $\mathrm{Fe}^{3+}$ was used to obtain yellow ${ }^{17}$ and acts as a reducing agent for copper so that it precipitates as metal or cuprite in brownish-red glasses. ${ }^{18-25}$ Copper was used to make blue-green and green glasses and cobalt generally for deep blue.

Raman and XRD analyses of the glaze of Chinese celadon shards, excavated in 1934 on Mapungubwe hill, re-dated the shards from its original classification as the Song dynasty (1127-1279 AD) to the Yuan (1279-1368 AD) or early Ming (1368$1644 \mathrm{AD})$ dynasties, which was an indication that the last occupation date of Mapungubwe may have been one to two centuries later than $1290 \mathrm{AD} .^{26}$ In order to obtain supportive evidence for these results a Raman spectroscopic study of the thousands of glass trade beads, excavated at the same site was initiated. ${ }^{27}$ First, an indepth study utilizing Raman spectroscopy and supportive techniques was conducted on the Mapungubwe oblates, the beads associated with the gold-bearing graves. ${ }^{27}$ The glass was found to be typical soda/lime/potash glass similar to Islamic glass from the $8^{\text {th }}$ century (Ommayad), ${ }^{27}$ but with higher levels of aluminium, iron and magnesium. The turquoise, bright green, bright yellow and orange colours were obtained by utilizing a combination of cassiterite $\left(\mathrm{SnO}_{2}\right)$ and lead tin yellow type II $\left(\mathrm{PbSn}_{1-}\right.$ ${ }_{\mathrm{x}} \mathrm{Si}_{\mathrm{x}} \mathrm{O}_{3}$ ). Doping with cobalt and manganese produced dark blue and plum coloured 
beads. $^{27}$ The Fe-S chromophore was detected through its resonance enhanced spectrum in the black beads. ${ }^{27}$ Corrosion of the black beads was investigated and an organic phase detected on the beads, which might have influenced the corrosion process. It has been shown that Raman spectroscopy can classify the glass matrix and provide unique information about the pigments used that is not possible with other analytical techniques. $^{29-31}$

The aim of this investigation is to extend the Raman spectroscopic study on the Mapungubwe Oblates ${ }^{27}$ to the other beads excavated at the Mapungubwe and K2 archaeological sites and to compile a Raman spectral database, which can be used as a guide to identify beads of this region with a fast and non-destructive technique.

\section{SAMPLES}

An assemblage of 175 beads that appeared to be different in shape, size and colour was selected from the formal Mapungubwe collection under the stewardship of the Department of Arts, University of Pretoria. The accessioned bead collection is extensive $\left(>100000\right.$ beads $\left.^{6}\right)$ and has accumulated over a 75 year period of archaeological excavation. The beads in this study were excavated on Mapungubwe hill and K2 and are mostly from the older excavations (1934-1938) of the grave area where most of the beads were found.

In Figure 3 representative examples of the beads studied are shown. A legend indicates the type of bead that could be identified according to the Wood classification system in Table $1 .^{6,13,14}$ It should be noted that the classification was done by comparing the beads to photos and some classifications could be wrong. Some of the beads studied do not fall under this classification system and was regarded to date from the last occupation of Mapunguwe hill which according to Gardner was the $19^{\text {th }}$ century and is indicated as "modern" on the figure. ${ }^{4}$ Only two of the beads in the figure are from the Mapungubwe Oblates series, for more details see reference 27 . The large wound bead is not a true oblate, but has a similar composition. 


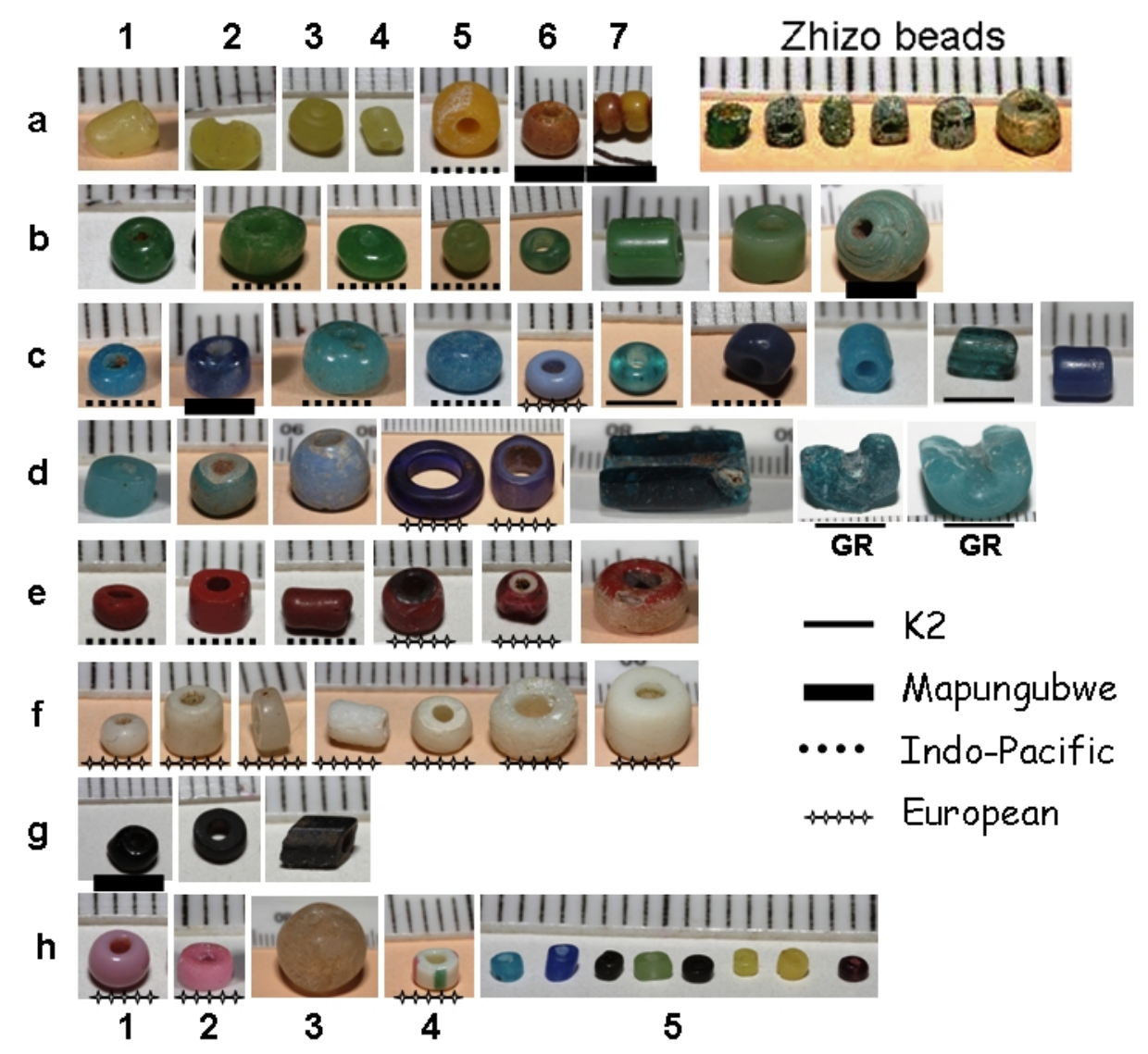

Figure 3: Representative beads excavated at Mapungubwe hill and $\mathrm{K} 2$ classified according to colour a) yellow, b) green, c-d) blue, e) red, f) white, g) black, h) others namely pink, quartz, striped and tiny arranged in the same order as the electronic database. ${ }^{28}$ Classifications according to the bead series in Table 1 are indicated, namely Zhizo, K2, Garden Roller (GR), Mapungubwe oblate and Indo-Pacific." 6,14 "Modern" corresponds to the class of bead described by Gardner and regarded as more recent. (scale: 1mm; Photograph : A. Carr).

\section{EXPERIMENTAL}

Micro-Raman spectroscopy was performed with a Labram Infinity, HR 800 and a T64000 micro-Raman spectrometers from HORIBA Scientific, Jobin Yvon Technology (Villeneuve d'Ascq, France).

All the beads were analysed with the HR 800 with a $514 \mathrm{~nm}$ Argon exciting laser (50mW at laser exit), a x50 objective and $600 \mathrm{t} / \mathrm{mm}$ grating with recording times ranging between 50-300s. The T64000 Raman spectrometer (514 nm laser) was used later to record spectra on some beads where no Raman signature or spectra of very poor quality were obtained with the HR 800 ( $\sim 10 \%$ of the spectra). In many cases where the Raman signal of the beads was low the edge filter of the HR 800 caused interferences in the form of a wavy background and as the T64000 spectrometer uses a triple monochromator system to eliminate contributions from the Rayleigh line, this 
aspect is eliminated. In the database ${ }^{28}$ an asterisk indicates the spectra recorded with the T64000.

The beads were analysed, if possible, on a clean part of the bead (more than one measurement for each bead) in order to obtain the Raman signature of the original glass without interference of corrosion products. In order to compare and identify the silicate glasses according to their Raman signatures, the fluorescence background was subtracted and the maximum positions of the bending and stretching bands respectively $\left(\delta_{\max } \mathrm{SiO}_{2}\right.$ and $v_{\max } \mathrm{SiO}_{2}$ ) were obtained to use for the classification of the glass matrix. ${ }^{22,31}$

A database with photographs of each of the beads analysed, museum reference number, excavation date, site (Mabungubwe hill, K2, Southern Terrace or Treasure pot), baseline corrected Raman spectrum, type of glass matrix $\left(\mathrm{Na}_{2} \mathrm{O}\right.$ or $\left.\mathrm{Na}_{2} \mathrm{O} / \mathrm{CaO}\right)$ and the pigment identified was compiled and available in reference 28.

\section{RAMAN RESULTS AND DISCUSSION}

\subsection{Glass matrix classification}

The Raman signature of an amorphous silicate is composed of two broad bands, one centred around $500 \mathrm{~cm}^{-1}$ and the other one around $1000 \mathrm{~cm}^{-1} \cdot 22,29-31$ The first represents bending vibrations of the $\mathrm{SiO}_{4}$ tetrahedron and the second stretching vibrations. The wavenumber maxima of the $\mathrm{Si}-\mathrm{O}$ bending and stretching bands are well-established tools for the classification of amorphous silicates,,$^{22,23,25,29-42}$ as illustrated in Figure 4 where the maximum positions of the bending $\left(\delta_{\max } \mathrm{SiO}_{2}\right)$ and stretching bands $\left(v_{\max } \mathrm{SiO}_{2}\right)$ of a very large collection of glass, varying in technology used, production period and origin, are plotted against each other. Specific areas on the plot represent different groups and representative compositions showing the composition range are also indicated. In general, an increase in alumina and lead concentration in the glass composition induces a bathochromic shift of the position of the bending and stretching bands respectively. ${ }^{25,27,32,36,37}$ Lixiviation also induces a wavenumber shift and a decrease in intensity. ${ }^{32,37}$ 


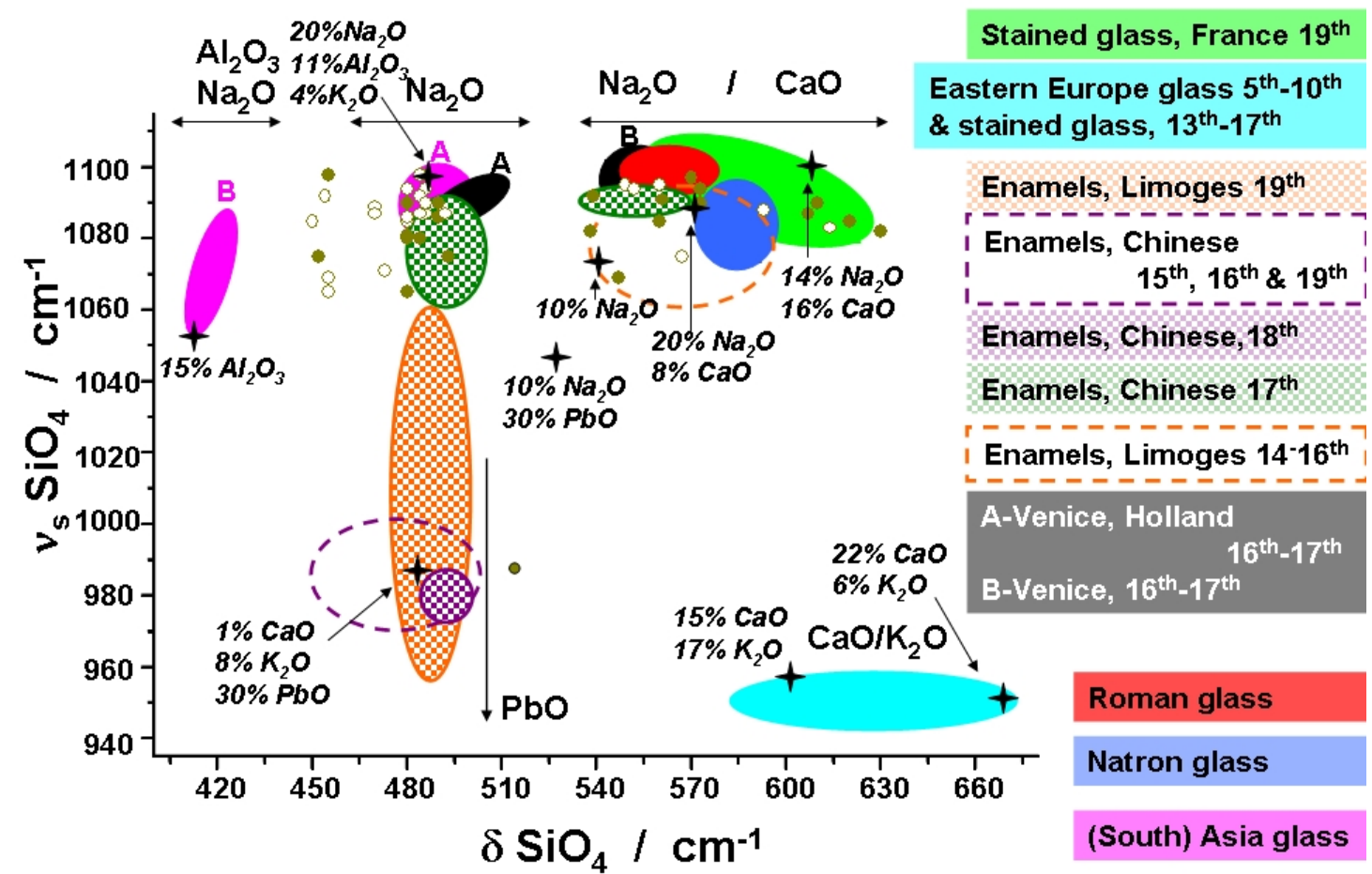

\section{$\circ$ K2 beads $\bigcirc$ Mapungubwe beads}

Figure 4: Classification of a large collection of glass by plotting the position of the $\mathrm{SiO}_{4}$ bending multiplet versus the stretching one, using data from the following articles Ricciardi et al., ${ }^{24,25}$; Kirmizi et al., ${ }^{35,36}$; Colomban et al., ${ }^{32}$ Tournié, ${ }^{34}$ and with the addition of the data of the beads excavated at Mapungubwe hill and K2. Representative compositions (major oxides) are given for each area (stars) delimiting the bending/stretching couple of values.

In Figure 4 the data extracted from the Raman spectra of the selection of beads excavated at Mapungubwe hill and K2 are also shown. The spectra used are free of significant bands originating from pigments, which could disturb the glass matrix. In some cases a decomposition treatment was used that made it possible to extract the required Raman parameters even when the pigment signature superimposes on that of the glass matrix. ${ }^{23,25,27,32}$ All the beads fit into two main groups, namely soda $\left(\mathrm{Na}_{2} \mathrm{O}\right)$ and soda-lime $\left(\mathrm{Na}_{2} \mathrm{O} / \mathrm{CaO}\right)$ glasses, which is in agreement with previous chemical analysis of the beads. ${ }^{2,3,5,10,11,13}$ Only one spectrum corresponds to a $\mathrm{PbO}$-rich composition. The large scattering of the data shows a variability of composition, which can be related to the raw materials used (mineral or sea plant ash for soda glass, continental plant ash for potash-lime glass), workshop technology or recycling of glass of different origins. Pigment addition can also shift the position of the bands. The beads excavated on Mapungubwe hill are well distributed between the $\mathrm{Na}_{2} \mathrm{O}$ and $\mathrm{Na}_{2} \mathrm{O} / \mathrm{CaO}$ groups, while the majority of beads excavated at $\mathrm{K} 2$ are in one group namely $\mathrm{Na}_{2} \mathrm{O}$. The diversity of the Mapungubwe hill beads arises from the longer 
occupation time of the site in comparison to the K2 site and indicates diverse origins of the beads.

Table 2: Average composition of the main beads series (K2, Garden

Roller (K2GR), K2, Indo-pacific and Mapungubwe oblate) excavated at Mapungubwe and $\mathrm{K} 2$ according to Robertshaw et. $a l .^{13}$

\begin{tabular}{|l|c|c|c|c|}
\hline & K2GR & K2 & $\begin{array}{c}\text { Indo- } \\
\text { Pacific }\end{array}$ & $\begin{array}{c}\text { Mapungubwe } \\
\text { oblate }\end{array}$ \\
\hline $\mathrm{Na}_{2} \mathrm{O}$ & 14.36 & $\mathbf{1 6 . 2 2}$ & 14.75 & 13.47 \\
\hline $\mathrm{MgO}$ & 0.37 & 0.43 & 0.59 & $\mathbf{5 . 8}$ \\
\hline $\mathrm{Al}_{2} \mathrm{O}_{3}$ & $\mathbf{1 6 . 6 3}$ & $\mathbf{1 1 . 8 5}$ & $\mathbf{1 3}$ & 7.67 \\
\hline $\mathrm{SiO}_{2}$ & 61.05 & 64.51 & 63.08 & 61.88 \\
\hline $\mathrm{K}_{2} \mathrm{O}$ & 3.39 & 3.34 & 3.46 & 3.47 \\
\hline $\mathrm{CaO}$ & 2.85 & 2.34 & 2.85 & $\mathbf{6 . 6 6}$ \\
\hline $\mathrm{Fe}_{2} \mathrm{O}_{3}$ & 1.35 & 1.3 & $\mathbf{2 . 2 7}$ & 104 \\
\hline $\mathrm{Type}$ & \multicolumn{3}{|}{} & $\mathbf{3}$ \\
\hline
\end{tabular}

In Figure 4 it can be seen that some of the beads (from both sites), with the bending band around $450 \mathrm{~cm}^{-1}$, form a new group outside the established groups related to the $\mathrm{Na}_{2} \mathrm{O}$ group. The majority of beads from the $\mathrm{K} 2$ site (stretching band around $1090 \mathrm{~cm}^{-1}$ ) are typical of South Asian glass and beads with stretching band around $1080 \mathrm{~cm}^{-1}$ are similar to Chinese Cloisonné enamel and glass from Venice and Holland $\left(16^{\text {th }}-17^{\text {th }}\right.$ c.) with a composition close to $20 \% \mathrm{Na}_{2} \mathrm{O}, 11 \% \mathrm{Al}_{2} \mathrm{O}_{3}$ and $4 \% \mathrm{~K}_{2} \mathrm{O}$ wt. $^{27,36,37}$ The beads excavated at Mapungubwe hill, which belong to the $\mathrm{Na}_{2} \mathrm{O} / \mathrm{CaO}$ group, exhibit bending bands between 540 and $630 \mathrm{~cm}^{-1}$ and are more scattered between groups than the beads from the $\mathrm{Na}_{2} \mathrm{O}$ group. The beads with bending band around $570 \mathrm{~cm}^{-1}$, are included in the Roman and Chinese Cloisonné enamel $\left(17^{\text {th }} \mathrm{c}\right.$.) areas with a composition close to $20 \% \mathrm{Na}_{2} \mathrm{O}$ and $8 \% \mathrm{CaO}$ wt. Mapungubwe beads with spectra with the bending band around $615 \mathrm{~cm}^{-1}$ fall into the area of the stained glass windows from $19^{\text {th }} \mathrm{c}$. with a composition close to $14 \% \mathrm{Na}_{2} \mathrm{O}$ and $16 \% \mathrm{CaO}$.

A more detailed classification of the glass types can be made by examining the shape of the vibrational signature that is directly related to the glass nanostructure and hence not only to the composition but also the production technology. In Figure 5, five representative Raman signatures of the glass matrix of all the collected spectra are shown. Type 1 (soda glass) is characterized by three bands at 320, 497 and 595 $\mathrm{cm}^{-1}$ for the bending band and three bands at 952, 991 and $1092 \mathrm{~cm}^{-1}$ for the stretching bands. Type 2 (soda-lime glass) is also characterized by 3 bands for the 
bending band, but only two bands for the stretching band at 943 and $1084 \mathrm{~cm}^{-1}$. Type 3 is a typical Roman type soda-lime glass. ${ }^{23,24,33,38}$

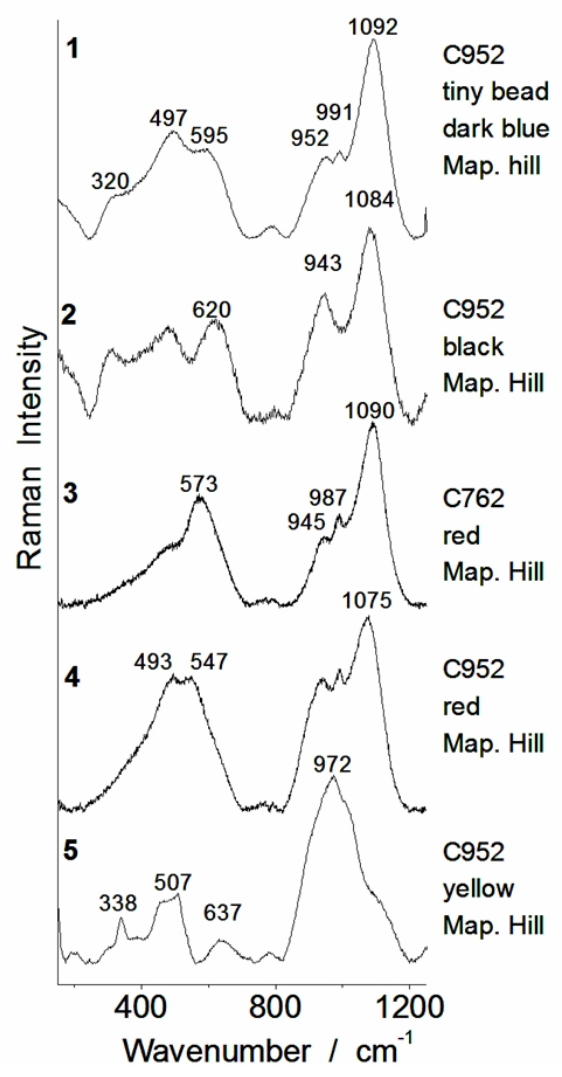

Figure 5: Representative Raman signatures of the five types of glass matrix observed among the assemblage of glass beads. Type 2 is a soda glass, Type 3 is soda-lime glass, Type 4 is a very corroded glass and Type 5 corresponds to the lead-rich composition. Type 2 seems to be an intermediate between Type 1 and 3 .

Type 2 can be considered as an intermediate between Type 1 and Type 3 and Type 4 is due to corrosion by acidic water. Previous studies have demonstrated that $\mathrm{K}^{+} / \mathrm{H}^{+}$substitution (lixiviation) induces an increase in intensity of the $\sim 480 \mathrm{~cm}^{-1}$ component in the bending multiplet and a move towards lower frequencies of the stretching maximum. $^{32,37}$ Comparing the spectra of types 3 and 4 it is clear that the intensity of the $492 \mathrm{~cm}^{-1}$ component has increased in Type 4, which indicates a modification of the O-Si-O angle in the $\mathrm{SiO}_{4}$ polymeric framework due to proton insertion. ${ }^{32,37,39,40}$ Also, a shift to lower wavenumbers, from $\sim 1090$ to $\sim 1075 \mathrm{~cm}^{-1}$, is observed for the stretching component and corresponds to a lengthening of the Si-O bond due to the interaction of the oxygen atoms with the inserted protonic species. Finally Type 5 is a lead-rich glass easily identified by a strong stretching mode at 972 
$\mathrm{cm}^{-1}$. A narrow component at $\sim 985 \mathrm{~cm}^{-1}$ could correspond to sulphate traces, ${ }^{41,42}$ a common phase in ancient glass.

Figure 6 focuses only on the data from beads excavated at Mapungubwe hill and K2. The glass matrix of the majority of beads excavated at the $\mathrm{K} 2$ site is Type 2, corresponding to the K2 and Indo-Pacific bead series. In contrast, the beads from the Mapungubwe hill excavation are distributed evenly among all the types of glass. These observations confirm the previous results obtained from Figure 4 namely that the data of the assemblage of beads from Mapungubwe hill is scattered broadly and may be related to many different origins and periods of production. It should be noted that the type of glass is determined from the general shape of the spectrum; thus, even if there is a bathochromic shift it can still be possible to recognise the original type of glass. If the lixiviation is too strong, the spectrum shape is distorted too much with a huge loss of intensity, the spectrum is assigned as Type 4 without a possibility to recognise the original type of glass.

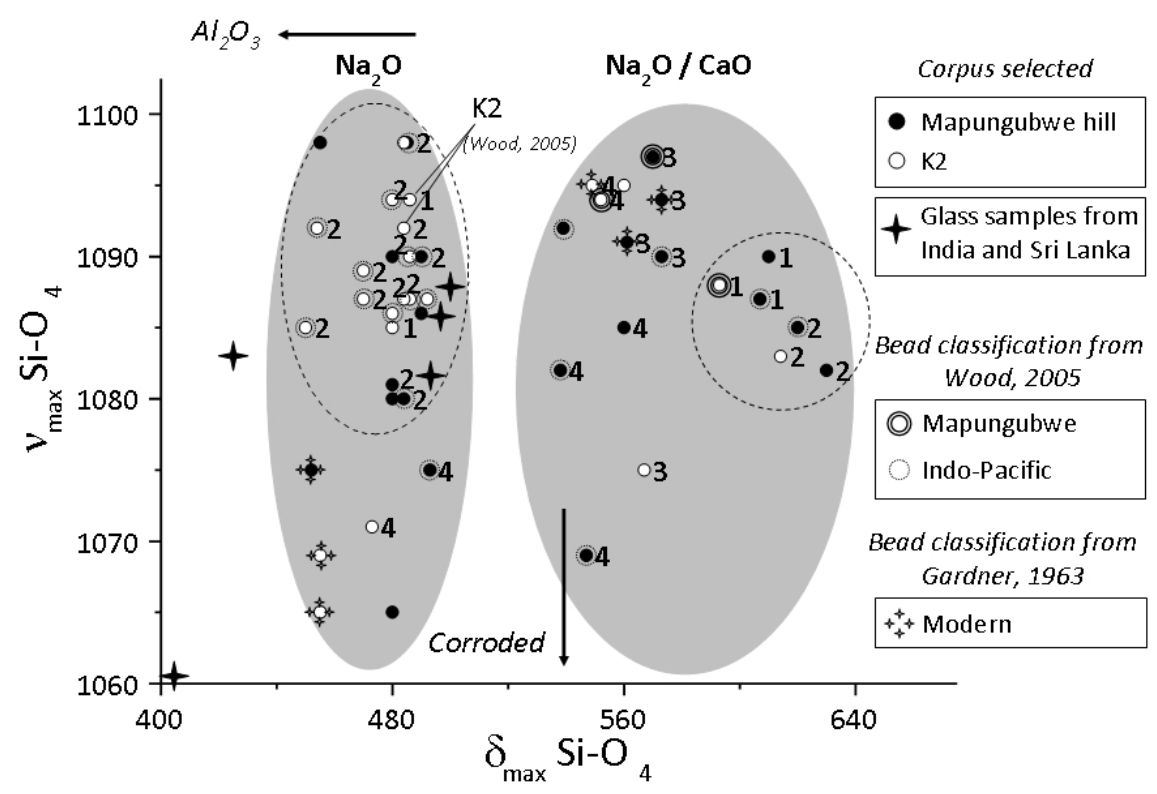

Figure 6: Classification of the glass beads from Mapungubwe hill and K2 sites by plotting the maximum positions of the bending and stretching bands of $\mathrm{SiO}_{4}$ against each other. The type of glass matrix $\left(\mathrm{Na}_{2} \mathrm{O}\right.$ and $\left.\mathrm{Na}_{2} \mathrm{O} / \mathrm{CaO}\right)$, the tendency of glass matrix $\left(\mathrm{Al}_{2} \mathrm{O}_{3}, \mathrm{PbO}\right.$ or corroded) and the bead series (K2, Mapungubwe, Indo-Pacific and European) are also indicated. 


\subsection{Pigments}

Raman spectrometry is a very efficient method to determine the type of pigment or chromophore used to colour glass and Table 3 summarises the pigments/chromophores and other crystalline phases identified in this study and incorporates the results of the study of the Mapungubwe Oblates. Bead colour, main Raman peaks, first production or origin and some references are also indicated. ${ }^{27}$

Table 3: Summary of colouring agents, opacifiers and other crystalline phases identified through their Raman spectra. Characteristic peak positions are indicated.

\begin{tabular}{|c|c|c|c|c|c|}
\hline $\begin{array}{l}\text { Coloring agent/ } \\
\text { 0pacifier/crystalline } \\
\text { phase }\end{array}$ & $\begin{array}{l}\text { Colour } \\
\text { bead }\end{array}$ & Phases & $\begin{array}{c}\text { Raman } \\
\text { peaks } / \mathrm{cm}^{-1}\end{array}$ & $\begin{array}{l}1^{\text {st }} \\
\text { production } \\
\text { origin }\end{array}$ & References \\
\hline Lazurite & turquoise & $\begin{array}{c}\mathrm{S}_{3}^{-} \text {and } \mathrm{S}_{2}^{-} \text {in } \\
\mathrm{Na}_{8}\left(\mathrm{Al}_{6} \mathrm{Si}_{6} \mathrm{O}_{24}\right) \mathrm{S}_{\mathrm{n}}\end{array}$ & 540 & $\begin{array}{l}\text { Synthetic } \\
\text { from } 1828\end{array}$ & 21,22 \\
\hline Calcium antimoniate & $\begin{array}{l}\text { Blue, } \\
\text { green, } \\
\text { white }\end{array}$ & $\mathrm{CaSb}_{2} \mathrm{O}_{7}$ & 480,634 & Antiquity & $24,25,53,54$ \\
\hline $\mathrm{Ca} / \mathrm{Pb}$ Arsenate & $\begin{array}{l}\text { Blue, } \\
\text { white, } \\
\text { pink, } \\
\text { striped }\end{array}$ & $\mathrm{CaAs}_{2} \mathrm{O}_{6}$ & 830 & $16^{\text {th }}$ c. in Italy & $25,36,57$ \\
\hline Chromate & blue & $\mathrm{CrO}_{4}$ ions & 844 & $18^{\text {th }} \mathrm{c}$. & $38,49,59$ \\
\hline Copper & Blue, red & $\mathrm{Cu}$ & 490 & Antiquity & 20 \\
\hline Cobalt & blue & $\mathrm{Co}$ & 605 & Antiquity & $48,49,59$ \\
\hline Yellow Naples & $\begin{array}{l}\text { Yellow, } \\
\text { green }\end{array}$ & $\begin{array}{l}\mathrm{Pb}_{2} \mathrm{Sb}_{2} \mathrm{O}_{7} \\
\text { pyrochlore }\end{array}$ & 144 & $\begin{array}{c}1^{\text {st }} \text { synthesis } \\
1570-1293 \\
\text { BC in ancient } \\
\text { Egypt }\end{array}$ & $17,21,25,35$ \\
\hline Stannate & $\begin{array}{l}\text { Yellow, } \\
\text { green }\end{array}$ & $\begin{array}{c}\mathrm{PbSnO}_{4} \\
\text { pyrochlore }\end{array}$ & 129,196457 & & $17,21,60$ \\
\hline $\begin{array}{l}\text { Clinopyroxene } \\
\text { diopside }\end{array}$ & green & $\mathrm{CaMgSi}_{2} \mathrm{O}_{6}$ & $390,665,1010$ & & 65 \\
\hline $\mathrm{Pb}-\mathrm{Sn}$ solid solutions & orange & pyrochlore & $\begin{array}{c}112,136, \\
280,427,528\end{array}$ & & 27 \\
\hline Amber & Black & $\begin{array}{c}\text { Fe-S } \\
\text { chromophore }\end{array}$ & 415 & $\begin{array}{c}\text { From India, } \\
\text { Sri Lank, } \\
\text { Mapungubwe }\end{array}$ & 27 \\
\hline Amber & Black & $\begin{array}{c}\text { Fe-S } \\
\text { chromophore } \\
\text { Mapungubwe } \\
\text { Oblate }\end{array}$ & $\begin{array}{l}290,332 \\
355,410\end{array}$ & Mapungubwe & 27 \\
\hline Spinel & Black & $\begin{array}{c}\mathrm{Fe}_{3-\mathrm{x}}[\mathrm{Co}, \mathrm{Cr} \\
\mathrm{Zn}]_{\mathrm{x}} \mathrm{O}_{4}\end{array}$ & 640 & & $44,59,62$ \\
\hline
\end{tabular}

\subsubsection{Blue}

Eight different Raman signatures were observed for the blue beads as shown in Figure 7. The lazurite signature, due to the sulphide ion chromophore, typical of natural lapis lazuli $^{43}$ or of synthetic ultramarine ${ }^{44,45}$ (Figure 7a (1), Table 3) is 
observed for several glass beads such as the one shown in Figure $3 \mathrm{c} 1$. Differentiation between lapis lazuli and ultramarine is not possible from their Raman spectra with visible excitation. Lapis lazuli was previously identified in some Iranian ceramic glazes made during the $13^{\text {th }} / 14 \mathrm{t}^{\mathrm{h}} \mathrm{c} .^{43}$ and is very common in Mamluk glasses from $13^{\text {th }}-15^{\text {th }} c .^{46,47}$ The use of lapis lazuli in these beads as pigment led us to assign them to an Islamic (Fustat or Iran) production.
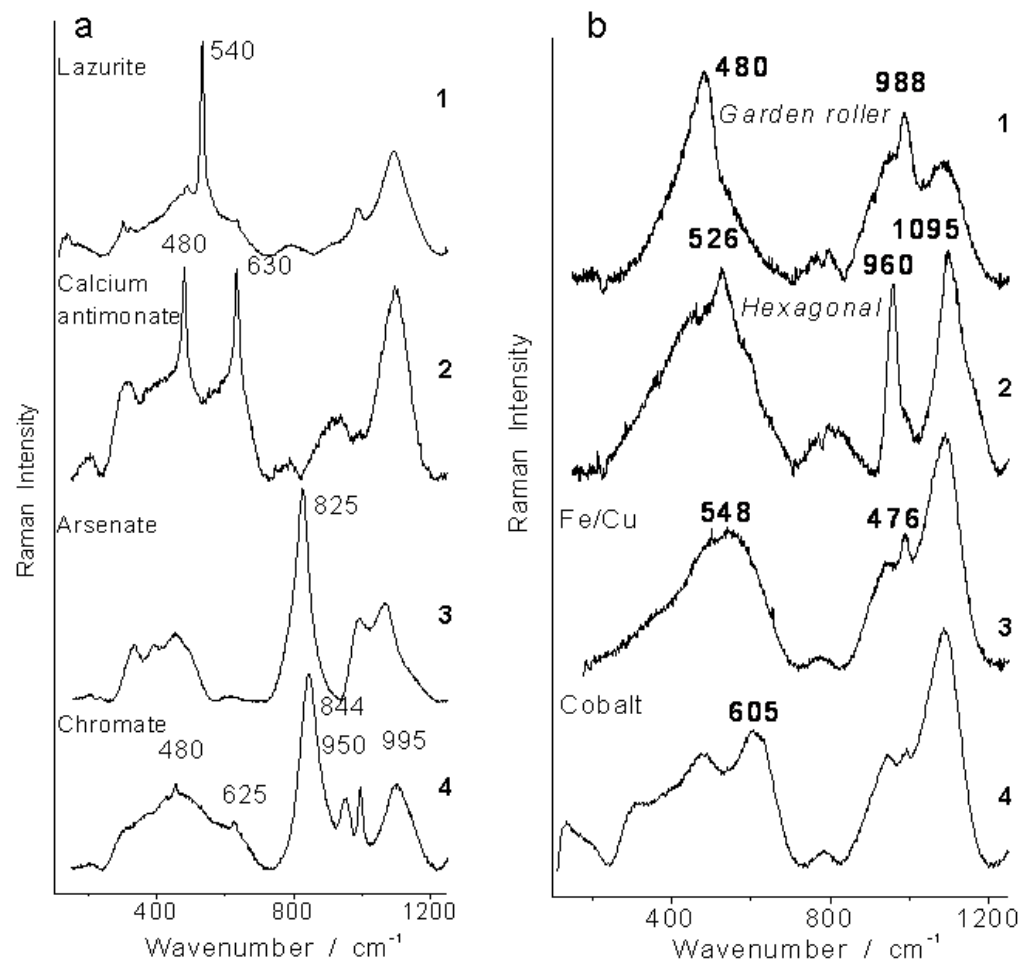

Figure 7a\&b: Representative Raman signatures recorded on blue beads excavated at Mapungubwe hill and K2.

The Raman spectrum of the blue bead in Figure $3 \mathrm{~d} 3$, exhibits an intense peak at $845 \mathrm{~cm}^{-1}$ (Figure 7a (4), Table 3) that may correspond to two phases: i) a chromate $\left(\mathrm{CrO}_{4}\right)$ as found in Iznik chromites ${ }^{46}$ and ii) cobalt silicate (nesosilicate) in some $18^{\text {th }}$ century porcelain glazes. ${ }^{38,49}$ Chromium is often associated with cobalt and refractory Cr-based second phase spectra may overlap the signature of Co-ones. Actually some Iranian and Asian cobalt sources consist of Co-Cr (Fe) or Co-Mn (Fe) ores. ${ }^{27,43,51,52}$

In spectrum 2 of Figure 7a, a pair of peaks at 480 and $630 \mathrm{~cm}^{-1}$ appears, which is typical of calcium antimonite. ${ }^{24,25,53}$ This pigment was used from antiquity, as opacifier or white pigment in Egypt. ${ }^{53-56}$ In Europe a transition was made from tin- 
rich to antimony-rich opacifiers during the $17^{\text {th }}$ century, which was again replaced by arsenic in the $18^{\text {th }}$ and $19^{\text {th }}$ centuries. ${ }^{56}$

A Raman signature of arsenate was observed (Figure 7a (3), Table 3) for milky blue beads (Figure $3 \mathrm{c5}$ ). The use of arsenate was developed in Italy (Venice) during the $16^{\text {th }} \mathrm{c} .^{57}$ to make lattimo glass but the use only spread out during the $19^{\text {th }} \mathrm{c}$. We assign this production to a $19^{\text {th }}$ c. import. The transition from $\mathrm{Sn}$ to $\mathrm{Sb}$ to $\mathrm{As}$ is then clearly illustrated in the beads found on Mapungubwe hill as previously observed for trade beads of Northeastern North America ${ }^{56}$ and indicates a long trading period.

The Raman spectrum in Fig. 7b (2) of a large cobalt blue hexagonal bead (Fig. 3 , d5) shows a narrow peak at $960 \mathrm{~cm}^{-1}$, characteristic of calcium phosphate as also observed in Islamic glazes, Medici porcelain and bone China glazes. ${ }^{25,48,49}$ The chromophore is the Co ion but calcium phosphate opacifier may modify the hue. These beads were produced in Czekoslovakia (Bohemia) and used during the slave trade. Examples occur at many archaeological sites in Africa and are popularly known as "Russians". 6

The Garden Roller beads (Figure 3 d6-7) analysed in this study are of the light green variety and the Raman spectrum in Figure $7 \mathrm{~b}$ (1) shows a sulphate signature ( $\mathrm{SO}_{4}{ }^{-}$stretching peak at $\sim 985 \mathrm{~cm}^{-1}, 41,42$ characteristic of a glass melt that have not been sufficiently annealed. This Raman signature is very close to a Raman signature of glass containing a high quantity of alumina. It has been shown that the Al content of the Garden Rollers is higher than that of the small beads that were used to make them and it has been attributed to contamination from the clay mould in which the beads were fired. ${ }^{14}$ This spectrum is also typical of corroded glass (Type 4) because of the peaks at 480 and $988 \mathrm{~cm}^{-1}$ previously attributed to corroded glass. ${ }^{32,33,37}$ This spectrum is not representative of the Garden Roller beads as there is a very large variation in colour and degree of vitrification between the beads and some spectra closely resembles a Type 3 glass. ${ }^{58}$ Optical microscopic examination of some bead fractures showed that in some instances the small beads could still be distinguished as separate entities. Consequently the composition of a Garden roller bead is not constant throughout the bead and Raman spectra will vary accordingly.

In spectra 3 and 4 of Figure $7 \mathrm{~b}$ there is no Raman signature of a pigment but only that of the glass matrix. Spectrum 3 in Figure $7 \mathrm{~b}$, characterized by a bending band at $548 \mathrm{~cm}^{-1}$, is observed for the blue beads typical of the $\mathrm{K} 2$ series and shown in Figure $3 \mathrm{c} 6$ and 9 . It has been determined with XRF analyses ${ }^{10,11}$ that the colouring 
agent in the $\mathrm{K} 2$ beads is copper or iron dissolved in the glass matrix, which has no special Raman signal. Spectra of the deep cobalt blue beads in Figure 7a (4) show an intense bending band at $605 \mathrm{~cm}^{-1}$ (Figure $3 \mathrm{c} 2,3, \mathrm{~d} 1$ ). The absence of a pigment signature indicates that the colour was obtained by dissolution of Co transition metal ions in the glass matrix. ${ }^{59}$

As for all turquoise coloured glass, the colour of Mapungubwe oblate beads results from copper in alkaline glass matrix. Lead tin yellow type II and cassiterite are added as opacifiers. ${ }^{27}$

\subsubsection{Yellow and green}

The bright yellow, for the Mapungubwe oblates, was obtained with lead tin yellow type II, as identified through Raman spectroscopy as well as XRF measurements. The Raman spectrum of lead tin yellow type II has bands at 138 (vs), 324 (m, br), which is very close to that of Naples Yellow (lead antimonite) (both pigments have the same pyrochlore structure) with bands at 140 (vs), 329 (m, br) and $448(\mathrm{w}, \mathrm{br}),{ }^{17,35,60,61}$ so it is not possible to distinguish unambiguously between the two pigments through their Raman spectra. Naples yellow as pigment was developed during the Renaissance period but it has been claimed that it was already present on tiles in Babylon from $16^{\text {th }}$ c. BC. ${ }^{22,55}$ Representative Raman signatures of yellow beads are shown in Figure $8 \mathrm{a}$ (1 and 2). The position of the strongest peak in the spectra varies between $136-144 \mathrm{~cm}^{-1}$, which shows that the pigments are all $\mathrm{Pb}-\mathrm{Sn}$-based pyrochlore solid solutions. ${ }^{36} \mathrm{Lead}$ (II) stannate, $\mathrm{Pb}_{2} \mathrm{SnO}_{4}$ (lead tin yellow Type 1) with two very strong peaks at 129 and $196 \mathrm{~cm}^{-1}$ was not observed.

Another type of $\mathrm{Pb}-\mathrm{Sn}$ solid solution was identified in Figure 8a (5) for the bright orange beads that forms part of the Mapungubwe oblates. ${ }^{27}$ Raman bands originating from lead tin yellow type II can be distinguished, but in addition a very strong signal at $112 \mathrm{~cm}^{-1}$ and a peak at $528 \mathrm{~cm}^{-1}$ are observed. The orange colour was obtained by adding lead to the mix and the extra peaks occur at wavenumbers very near to that of red lead oxide. ${ }^{27}$ A similar spectrum has previously been reported in Islamic ceramics from Dougga in Ifriqiya, one sample dating from the $11^{\text {th }}-12^{\text {th }}$ century (Zirides period), the other from the $17^{\text {th }}-18^{\text {th }}$ century (Ottoman period). ${ }^{61}$

The bright green of the small opaque Mapungubwe oblates was obtained by a combination of lead tin yellow type II and copper ions. ${ }^{27}$ Two other Raman signatures were observed for green beads as shown in Figure 8a (3 and 4). One (3) is assigned to 
calcium antimonate which confers to the bead a milky aspect (Figure 3 b6,7) and the colouring element is certainly copper because copper ions do not form specific phases that can be recognised in a Raman spectrum. The second one (4) corresponds to a large wound bead (Figure $3 \mathrm{~b} 8$ ) found on Mapungubwe hill and the sharp peaks at $\sim 328,395,671$ and $1015 \mathrm{~cm}^{-1}$ is characteristic of the clinopyroxene diopside. This is consistent with the large $\mathrm{Mg}$ content (Table 2) and indicates a thermal treatment above $900-1000^{\circ} \mathrm{C}$ but not sufficient for a complete homogeneisation of the glass. The Raman signature of diopside has previously also been detected in a glass paste vase from Egypt (6th-5th century BC). ${ }^{54,55}$
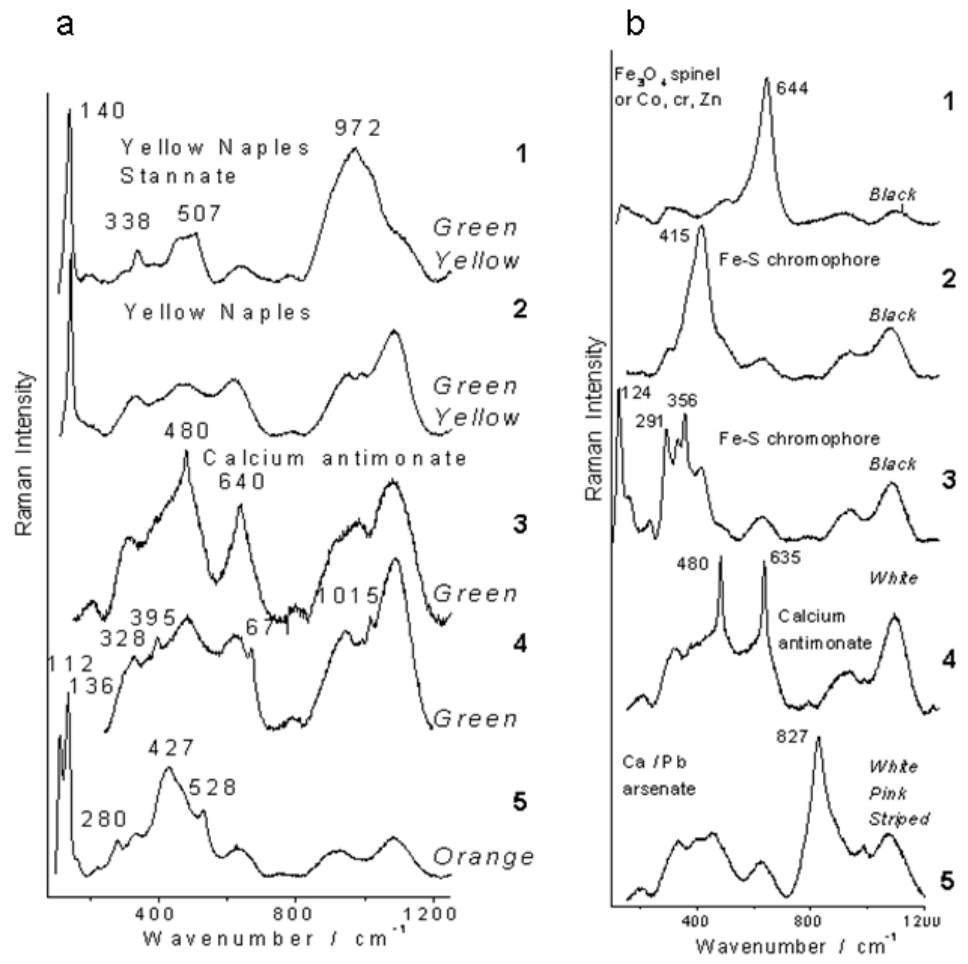

Figure 8: Representative Raman signature of a) yellow and green beads and b) black and white beads excavated at Mapungubwe hill and K2.

\subsubsection{Black and white}

Three representative Raman signatures for black beads are shown in Figure $8 \mathrm{~b}$ (1-3). The black pigment of the thousands ( $>50000)$ of black beads associated with the middle period of Mapungubwe was identified as a Fe-S chromophore, which is used to produce amber glass. ${ }^{27}$ The majority of the black beads are Mapungubwe Oblates, represented by the spectrum with a few sharp peaks in Figure $8 \mathrm{~b}$ (3). The 
position, relative intensities and number of peaks vary on different positions on a bead and also between beads (for more details see reference 28). For larger cylindrical and round beads the Fe-S peak is very strong and appears at $415 \mathrm{~cm}^{-1}$ (Table 3), indicating that they were not produced in the same way as the oblates. Although the Raman spectra of the large round and cylindrical beads are similar, their chemical composition differs from each other and from the oblates and therefore might have different origins or periods of production at the same site. A similar spectrum of the Fe-S chromophore of the large cylindrical and round beads is also obtained from black South Indian and Sri Lanka glass samples. ${ }^{27}$ In this study we identified another pigment (Fig. 8b (1)) for black beads corresponding to the spinel $\mathrm{Fe}_{3} \mathrm{O}_{4}$ or $\mathrm{Co}, \mathrm{Cr}, \mathrm{Zn}$ substituted homologues ${ }^{44,62}$ and this is an indication that the black beads probably even had a fourth production centre.

Two different pigments were detected for the white beads; calcium antimonate and $\mathrm{Ca} / \mathrm{Pb}$ arsenate (Figure $7 \mathrm{~b}$, Table 3). The arsenate were also detected on the pink (Figure $3 \mathrm{~h} 1,2$ ) and striped beads (Figure $3 \mathrm{~h} 4$ ) which are typical modern beads and in agreement with Gardner's classification

\subsection{Glass matrix, pigments and place/period of production}

Table 4 summarizes the assignments for the different beads. The glass matrixes of the lazurite coloured beads (glass Types 2 and 3, Figure 5) and beads containing calcium antimonate are distributed into both the $\mathrm{Na}_{2} \mathrm{O}$ and $\mathrm{Na}_{2} \mathrm{O} / \mathrm{CaO}$ (Figure 9) groups. This implies that these blue beads have two different origins or periods of production. The glass matrixes of the arsenate-based blue beads and copper blue beads fit into the $\mathrm{Na}_{2} \mathrm{O}$ groups with a majority displaying the Type 1 Raman signature. The cobalt blue beads fit in the $\mathrm{Na}_{2} \mathrm{O} / \mathrm{CaO}$ groups (Figure 9) with a majority of Types 1 and 2 and a few of Type 3 Raman signatures

The red beads belong in both groups $\mathrm{Na}_{2} \mathrm{O}$ and $\mathrm{Na}_{2} \mathrm{O} / \mathrm{CaO}$ and the majority of the Raman spectra is Type 4 (corroded glass, Figure 9). A red coloured glass was obtained from Neolithic times ${ }^{20}$ and references herein by distributing copper nanoparticles in a glass matrix and very large quantities of red glass were produced during Roman times. $^{23,24}$ Note that in this reference $1075 \mathrm{~cm}^{-1}$ is the position of the stretching massive of uncorroded red $\mathrm{Cu}^{0}$ containing glass, likely due to some lead addition) and 
continued in Islamic productions. Copper corrosion is easy and explains the beads degradation.

Table 4: Summary of beads classified and analysed in this study regarding to colour and glass matrix. Raman signature type and quantity of representative beads that was analysed where available the quantity of similar beads in the bead collection is also given. Possible origins for the beads based on the pigment identified are also given.

\begin{tabular}{|c|c|c|c|c|c|c|}
\hline \multirow{2}{*}{ Pigment/Chromophore } & \multirow{2}{*}{ Quantity } & \multirow{2}{*}{ Measured } & \multicolumn{3}{|c|}{ Glass matrix } & \multirow{2}{*}{$\begin{array}{c}\text { Possible origin / Period of } \\
\text { trade }\end{array}$} \\
\hline & & & $\mathrm{Na}_{2} \mathrm{O}$ & $\mathrm{Na}_{2} \mathrm{O} / \mathrm{CaO}$ & Type & \\
\hline Blue/Lazurite & 400 & 6 & $\mathrm{x}$ & $\mathrm{x}$ & 3,2 & $\begin{array}{c}\text { Islamic production } \\
\text { Fustat / Iran }\end{array}$ \\
\hline Blue/Arsenate & 400 & 9 & $\mathrm{x}$ & & & Italy, $19^{\text {th }}$ century \\
\hline White/Arsenate & 50 & 12 & $\mathrm{x}$ & & & Italy, $19^{\text {th }}$ century \\
\hline Striped/Arsenate & 10 & 2 & & & & Italy, $19^{\text {th }}$ century \\
\hline Pink/Arsenate & 550 & 2 & & & & Italy, $19^{\text {th }}$ century \\
\hline Blue/copper & $>8000^{6}$ & 16 & $\mathrm{x}$ & & $\mathbf{1}, 2$ & Indo-Pacific \\
\hline Red/copper & $>2000^{6}$ & 30 & $\mathrm{x}$ & $\mathrm{x}$ & $2,3,4$ & Indo-Pacific \\
\hline Blue/Cobalt & 930 & 15 & & $\mathrm{x}$ & $1,2,3$ & Many possibilities \\
\hline Blue/chromate & 50 & 3 & & & & Middle East, Iran \\
\hline Blue/Ca antimonate & 450 & 5 & $\mathrm{x}$ & $\mathrm{x}$ & 2 & Europe/ Egypt, China \\
\hline Green/Ca antimonate & 10 & 4 & $\mathrm{x}$ & & & Europe/ Egypt, China \\
\hline White/Ca antimonate & 500 & 8 & & $\mathrm{x}$ & 3 & Europe/ Egypt, China \\
\hline $\begin{array}{l}\text { Green/Lead Tin } \\
\text { yellow Type II/Naples } \\
\text { Yellow }\end{array}$ & $>900^{6}$ & 13 & $\mathrm{x}$ & only 1 & 2 & $\begin{array}{c}\text { Middle East / Indo-Pacific } \\
\text { /Europe }\end{array}$ \\
\hline $\begin{array}{l}\text { Yellow/Lead tin } \\
\text { yellow Type II/Naples } \\
\text { yellow }\end{array}$ & $>1900^{6}$ & 15 & $\mathrm{x}$ & & 4 & $\begin{array}{c}\text { Middle East / Indo-Pacific } \\
\text { /Europe }\end{array}$ \\
\hline Black/Spinel & unknown & 2 & & $\mathrm{x}$ & & Unknown \\
\hline $\begin{array}{l}\text { Black/Fe-S } \\
\text { chromophore }\end{array}$ & $>80000^{6}$ & 18 & & $\mathrm{x}$ & & Indo-Pacific \\
\hline
\end{tabular}

The green and yellow beads with $\mathrm{Ca}$ antimonate and Naples yellow / lead tin yellow type 2 belong to the $\mathrm{Na}_{2} \mathrm{O}$ group except one green bead (Figure 9). For other beads also coloured with Naples yellow / lead tin yellow type 2, the Raman signature of the green bead is Type 2 and the yellow one is Type 4 (Roman like glass corroded).

The white beads coloured with arsenate fit into to the $\mathrm{Na}_{2} \mathrm{O}$ group while $\mathrm{Ca}$ antimonate white beads belong to the $\mathrm{Na}_{2} \mathrm{O} / \mathrm{CaO}$ group (Type 3). Finally, the black beads belong to the $\mathrm{Na}_{2} \mathrm{O} / \mathrm{CaO}$ groups. 


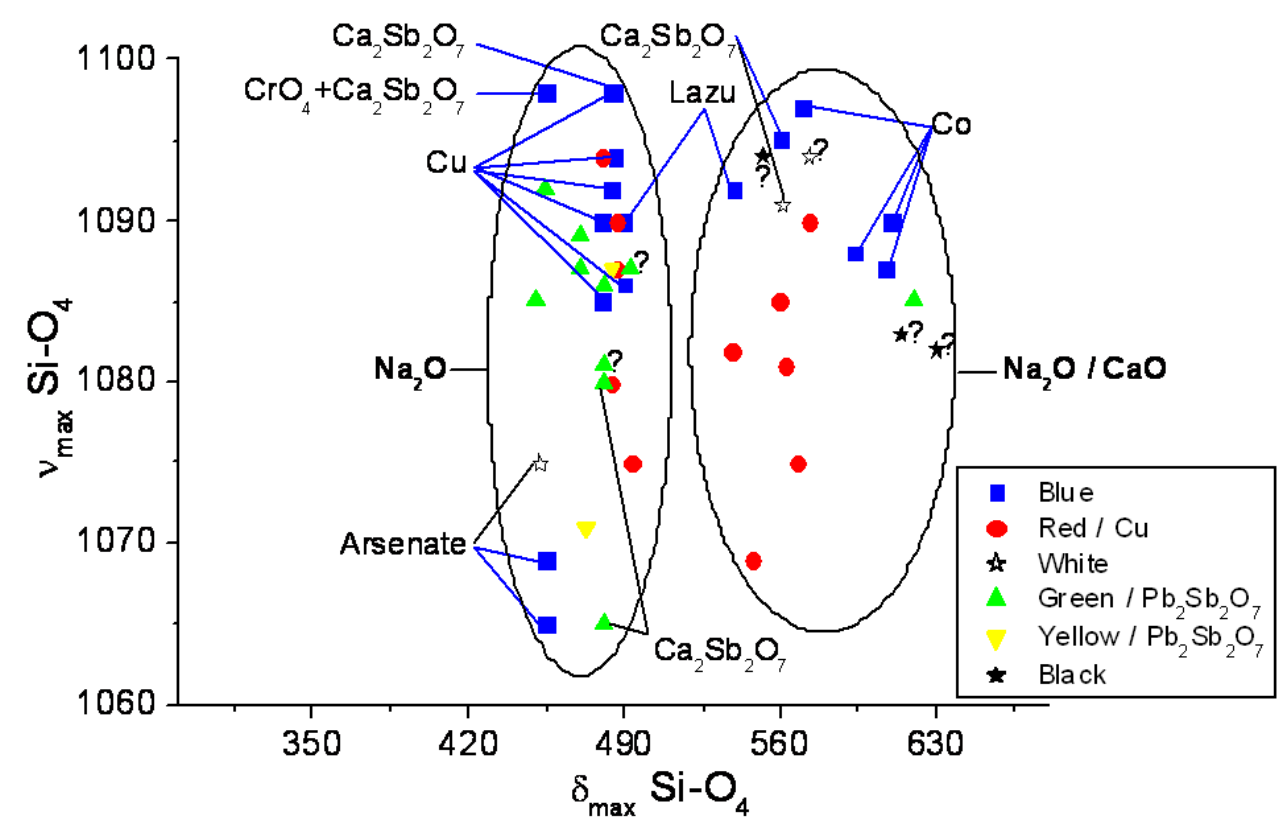

Figure 9: Classification of the glass beads from Mapungubwe hill and K2 sites according to the bending and stretching bands of $\mathrm{SiO}_{4}$. The colour and pigments used to colour the beads are indicated. Question marks indicate beads where the pigments could not be identified using Raman spectroscopy.

It is therefore possible to speculate about the number of possible origins and/or periods of production for each colour of Mapungubwe hill and K2 beads. For example 6 techniques were used to colour the blue beads and some pigments are identified in two different glass matrixes, for example lazurite and blue antimonate. So, in total there might be approximatively 8 possible origins or periods of production for blue beads spread between Europe, Indo-Pacific and Middle East. Regarding the white beads, 2 pigments were observed with Raman spectrometry, both associated with bead production in Europe. The pink and striped beads also containing arsenate probably originate from the same location as the white beads containing arsenate. The next step will be to analyse historic beads from possible production centres to find a final answer.

The beads that we analysed in during this study that we found to originate from Europe and dates after 1290AD are representative of similar beads that amount to more than 2000 beads in the collection. This is a significant quantity and indicates a longer occupation time on the hill which lasted well after the $14^{\text {th }} \mathrm{c}$. and at least until the $19^{\text {th }} \mathrm{c}$. 


\section{CONCLUSION}

It was possible to classify the beads into two groups using the parameters extracted from their Raman signatures, namely soda and soda/lime glass. The classification is in accordance with previous work where other analytical techniques were used to determine the type of glass matrix. It provides an easy non-destructive method for archaeologist to discriminate non-destructively between bead types, when it is not possible to differentiate between beads on morphological factors alone.

The strength of Raman spectroscopy was illustrated in identifying the pigments used to colour the beads. Many of them was first used after the $13^{\text {th }}$ century some even dating from the $19^{\text {th }}$ century. This supports our previous results, which found that the celadon shards excavated on the hill dates from a later period than the original classification and indicates a later occupation date for the hill. This calls for more research to find a way to reconcile the carbon dating of the hill with the physical evidence of the modern beads excavated on the hill. ${ }^{63} \mathrm{~A}$ few pigments were identified that is typical of Islamic productions and is supportive of previous authors who claimed Fustat to be a possible production site. The presence of celadon shards at the site indicates that the beads could also have been produced in China and a recent Raman study identified calcium antimonite as opacifier in beads excavated in China ${ }^{64}$, which might change the attribution of these beads from Europe to China. As the body of Raman work on beads progress around the world the possibility of identifying the exact origin of beads will increase.

The information obtained from identifying both pigments and type of glass matrix of the beads indicates a large number of production sites and therefore a considerable quantity of trading partners over a long period of time. Future, more indepth studies of the beads, where other parameters extracted from their Raman signatures such as polymerisation index are also used might even reveal more production origins.

\section{ACKNOWLEDGEMENTS}

The authors thank Ms Sian Tiley and Ms Isabelle Barrier, Curator and Assistant Curator of the Mapungubwe Museum for their help and advice. Dr Leskey Cele and the Tshwane University of Technology are kindly acknowledged for the permission to 
use their Raman facilities. We gratefully acknowledge the financial support of NRF/CNRS, LADIR and the University of Pretoria.

We also thank Dr Alan Carr for the photographs of the bead samples. Dr B. Gratuze and L. Dussubieux are kindly acknowledged for the South Asian glass references. 


\section{REFERENCES}

1. L. Fouché, Mapungubwe: ancient Bantu civilization on the Limpopo, Cambridge University Press: Cambridge, 1937, p1.

2. S.J. Saitowitz . Glass beads as indicators of contact and trade in southern Africa $c a$. AD 900-AD 1250, unpublished PhD Thesis, University of Cape Town: Cape Town, 1996.

3. S.J. Saitowitz, D.L. Reid, N.J. Van der Merwe, South African J. Sci. 1996, 92, 101.

4. G.A. Gardner, in Mapungubwe, II, J. L. van Schaik Ed.: Pretoria, 1963, pp 1-25, $32-$ $35 \& 81-92$.

5. C.C. Davison, African Studies 1973, 32, 247.

6. M. Wood, South-Africa Archaeological Society-Goodwin Series 2000, 8, 78.

7. H.C. Beck, The beads of the Mapungubwe District, in: Mapungubwe, L. Fouché Ed., Cambridge University Press: Cambridge, 1937, p. 104-113

8. C. Van Riet Lowe, The Glass Beads of Mapungubwe, Archaeological Series No. 9. Union of South Africa, Archaeological Survey: Pretoria, 1955.

9. W.G.N. Van der Sleen, Man, 1956, 56, 27.

10. C.C. Davison, J.D. Clark, Azania 1974, 9, 75.

11. C.C. Davison, Three chemical groups of glass beads at the Greefswald sites, in Die kultuur van Greefswald, J.F. Eloff Ed., unpublished report for the Human Sciences Councils, vol. 2, University of Pretoria: Pretoria, 1979, p1-39.

12. J.C. Vogel, South-Africa Archaeological Society-Goodwin Series 2000, 8, 51.

13. P. Robertshaw, M. Wood, E. Melchiorre, R. S. Popelka-Filcoff, M. D. Glascock, J. Archaeol. Sci. 2010, 37, 1898.

14. M. Wood, Glass beads and Pre-European trade in the Shashe-Limpopo-region, Unpublished MsC Thesis, University of the Witwatersrand: Johannesburg, 2005.

15 P. Francis, Jr. Asia's Maritime Bead Trade: 300 B.C. to the Present. University of Hawai'i Press: Honolulu, 2002.

16. M. S. Tite, I. M. Freestone, R. Mason, J. Molera, M. Vendrell-Saz, N. Wood Archaeometry 1998, 40, 241.

17. M. Pereira, T. de Lacerda-Aroso, M.J.M. Gomes, A. Mata, L.C. Alves, Ph. Colomban, J. Nano Research 2009, 8, 79.

18. K. Nassau, The physics and chemistry of color: the fifteen causes of color, $2^{\text {nd }}$, John Wiley \& Sons: New York, 2001.

19. Ph. Colomban, H. Schreiber, J. Raman Spectrosc. 2005, 36, 884.

20. Ph. Colomban, J. Nano Research 2009, 8, 109.

21. L. Burgio, R. J. H. Clark, Spectrochemica Acta Part A 2001, 57, 1491.

22. Ph. Colomban, J. Non-Crystall. Solids 2003, 323, 180.

23. Ph. Colomban, G. March, L. Mazerolles, T. Karmous, N. Ayed, A. Ennabli, H. Slim, J. Raman Spectrosc. 2003, 34, 205.

24. P. Ricciardi, Ph. Colomban, A. Tournié, M. Macchiarola, N. Ayed, J. Archaeol. Sci. 2009, 36, 2551.

25. P. Ricciardi, Ph. Colomban, A. Tournié, V. Milande, J. Raman Spectrosc. 2009, 40, 604.

26. L. C. Prinsloo, N. Wood, M. Loubser, S. M. C. Verryn, S. Tiley, J. Raman Spectrosc. 2005, 36, 806.

27. L. C. Prinsloo, Ph. Colomban, J. Raman Spectrosc. 2008, 39, 79.

28. A. Tournié, L. Prinsloo, Ph. Colomban, Raman classification of the glass beads excavated on Mapungubwe hill and K2, Archaeological sites in South Africa, 
University of Pretoria Internal Report, HAL, http://hal.archives-ouvertes.fr/hal00543867_v1/, 2010 (accessed July 2011).

29. T. Furukawa, K.E. Fox, W.B. White, J. Chem. Phys. 1981, 75, 3226.

30. P. McMillan, B. Piriou, J. Non-Crystall. Solids 1982, 53, 279.

31. Ph. Colomban, A. Tournié, L. Bellot-Gurlet, J. Raman Spectrosc. 2006, 37, 841.

32. A. Tournié, P. Ricciardi, Ph. Colomban, Solid State Ionics 2008, 179, 2142.

33. A. Tournié, Analyses Raman sur site de verres et vitraux anciens : modélisation, procedures, lixiviation et caractérisation, Université Pierre-et-MarieCurie Thesis: Paris, 2009 (http://www.ladir.cnrs.fr/pages/theses/These_Aurelie Tournie.pdf).

34. Ph. Colomban, A. Tournié, J. Cultural Heritage, 2007, 8, 242.

35. B. Kirmizi, Ph. Colomban, B. Quette, J. Raman Spectrosc. 2010, 41, 780.

36. B. Kirmizi, Ph. Colomban, M. Blanc, J. Raman Spectrosc. 2010, 41, 1240.

37. Ph. Colomban, M.-P. Etcheverry, M. Asquier, M. Bounichou, A. Tournié, J. Raman Spectrosc. 2006, 37, 614.

38. Ph. Colomban, Glasses, glazes and ceramics-Recognition of the ancient technology from the Raman spectroscopy in Raman Spectroscopy in Archaeology and Art History, H.G.M. Edwards \& J.M. Chalmers Eds, Royal Society of Chemistry: Cambridge, 2005, p.192.

39. T. Scanu, J. Guglielmi, Ph. Colomban, Solid State Ionics, 1994, 70-71, 109.

40. S. K. Sharma, B. Simons, H. S. Yoder, Am. Mineral. 1983, 68, 1113.

41. W.L. Konijnendijk, J.H.J.M. Buster, J. Non-Crystall. Solids 1977, 23, 401.

42. M. Lenoir, A. Grandjean, S. Poissonnet, D.R. Neuville, J. Non-Crystall. Solids 2009, 355, 1468.

43. Ph. Colomban, J. Raman Spectrosc. 2003, 34, 420.

44. M.C. Caggiani, Ph. Colomban, J. Raman Spectrosc. 2011,42,790.

45. E. Picquenard, O. El Jaroudi, J. Corset, J. Raman Spectrosc. 1993, 24, 11.

46. $\mathrm{Ph}$. Colomban, G. Fellinger, S. Makariou, to be published.

47. R. Ward Ed., Gilded and enamelled glass from the Middle-East, British Museum Press: London, 1998.

48. Ph. Colomban, V. Milande, H. Lucas, J. Raman Spectrosc. 2004, 32, 68.

49. H. G. M. Edwards, Ph. Colomban, B. Bowden, J. Raman Spectrosc. 2004, 35, 656.

51. Ph. Colomban, G. Sagon, L.Q. Huy, N.Q. Liem, L. Mazerolles, Archaeometry 2004, 46, 125.

52. B. Gratuze, I. Soulier, J.-N. Barrandon, D. Foy, Revue d'Archéométrie 1992, 16, 97.

53. V. Gedzeviciûtë, N. Welter, U. Schüssler, C. Weiss, Achaeol. Anthropol. Sci. 2009, $1,15$.

54. J. L. Mass, R. E. Stone, M. T. Wypyski, The mineralogical and metallurgical origins of roman opaque colored glasses, in The prehistory and history of glassmaking technology, W.D Kingery. \& P. McGray Eds, Ceramics and Civilization VIII. Amer. Ceram. Soc.:Westerville (Ohio), 1998, pp121-144.

55. J. L. Mass, M. T. Wypyski, R. E. Stone, Archaeometry 2002, 44, 5.

56. S. M. L. Sempowski, A. W. Nohe, J. F.Moreau, J. Radioanal. Nuclear Chem. 2000, 244, 559.

57. M. Verità, in Medieval mosaics: light, colour, materials, G.S.F. Borsook E., Pagliarulo G.: Florence, 2000. 
58. L. C. Prinsloo, Ph. Colomban, A. Tournié, 4th International Conference on the Application of Raman Spectroscopy in Art and Archaeology, Modena, 3 - 7 Sept. 2007.

59. Ph. Colomban, G. Sagon, X. Faurel, J. Raman Spectrosc. 2001, 32, 351.

60. I. M. Bell, R. J. H Clark, P. J. Gibbs, Spectrochimica Acta Part A 1997, 53, 2159.

61. Ph, Colomban, G. Sagon, A. Louchi, H. Binous, N. Ayed, Revue d'Archéométrie 2001a, 25, 101.

62. Ph. Colomban, S. Cherifi, G. Dexpert, J. Raman Spectrosc. 2008, 39, 881.

63. L.C. Prinsloo, Ph. Colomban, A. Tournié, J. Archaeol. Sci. 2011, in press.

64. H. Zhao, H. Cheng, Qinghui, and F. Gan, 2011, Chinese Optics letters, 9,(3), 033001-1.

65. G. Simsek, Ph. Colomban, V. Milande, J. Raman Spectrosc. 2010, 41, 529. 